\title{
Microbiological and chemical attributes of a Hapludalf soil with swine manure fertilization
}

\author{
Rafael da Rosa Couto(1), Jucinei José Comin(2), Cláudio Roberto Fonsêca Sousa Soares(2), Paulo Belli Filho(1), \\ Lucas Benedet ${ }^{(2)}$, Marcel Pires de Moraes ${ }^{(2)}$, Gustavo Brunetto(2) and Caetano Luiz Beber ${ }^{(3)}$
}

\begin{abstract}
(1)Universidade Federal de Santa Catarina (UFSC), Centro Tecnológico, Caixa Postal 476, CEP 88040-970 Florianópolis, SC, Brazil. E-mail: rrccouto@hotmail.com, belli@ens.ufsc.br (2)UFSC, Centro de Ciências Agrárias, Rodovia Admar Gonzaga, oㅜ1.346, CEP 88034-000 Florianópolis, SC, Brazil. E-mail: jcomin@cca.ufsc.br, crfsoares@gmail.com, lucas_benedet@hotmail.com, brunetto.gustavo@gmail.com ${ }^{(3)}$ Centre International d'Études Supérieures en Sciences Agronomiques, 2 place Pierre Viala 34060 Montpellier, France. E-mail: caetano.beber@supagro.inra.fr
\end{abstract}

\begin{abstract}
The objective of this work was to evaluate the microbiological and chemical attributes of a soil with a seven-year history of urea and swine manure application. In the period from October 2008 to October 2009 , soil samples were collected in the $0-10 \mathrm{~cm}$ layer and were subjected to the treatments: control, without application of urea or manure; and with the application of urea, pig slurry, and deep pig litter in two doses, in order to supply one or two times the recommended $\mathrm{N}$ doses for the maize (Zea mays)/black oat (Avena strigosa) crop succession. The carbon of the microbial biomass (MB-C) and the basal respiration $\left(\mathrm{C}-\mathrm{CO}_{2}\right)$ were analyzed, and the metabolic $\left(q \mathrm{CO}_{2}\right)$ and microbial quotient $(q \mathrm{mic})$ were calculated with the obtained data. Organic matter, $\mathrm{pH}$ in water, available $\mathrm{P}$ and $\mathrm{K}$, and exchangeable $\mathrm{Ca}$ and $\mathrm{Mg}$ were also determined. The application of twice the dose of deep pig litter increases the $\mathrm{MB}-\mathrm{C}$ and $\mathrm{C}-\mathrm{CO}_{2}$ values. The $q$ mic and $q \mathrm{CO}_{2}$ are little affected by the application of swine manure. The application of twice the dose of deep pig litter increases the values of $\mathrm{pH}$ in water and the contents of available $\mathrm{P}$ and of exchangeable $\mathrm{Ca}$ and $\mathrm{Mg}$ in the soil.
\end{abstract}

Index terms: environmental quality, no-tillage, pig slurry, soil quality, swine production.

\section{Atributos microbiológicos e químicos de um Argissolo adubado com esterco de suínos}

Resumo - O objetivo deste trabalho foi avaliar os atributos microbiológicos e químicos de um solo com histórico de sete anos de aplicação de ureia e dejetos de suínos. No período de outubro de 2008 a outubro de 2009 , foram coletadas amostras de solo na camada de $0-10 \mathrm{~cm}$, as quais foram submetidas aos tratamentos: controle, sem aplicação de ureia ou dejetos; e com a aplicação de ureia, dejetos líquidos e cama sobreposta de suínos em duas doses, para suprir uma ou duas vezes a dose de $\mathrm{N}$ recomendada para a sucessão milho (Zea mays)/aveia-preta (Avena strigosa). $\mathrm{O}$ carbono da biomassa microbiana (C-BM) e a respiração basal $\left(\mathrm{C}-\mathrm{CO}_{2}\right)$ foram analisados, e o coeficiente metabólico $\left(q \mathrm{CO}_{2}\right)$ e o microbiano $(q$ mic $)$ foram calculados com os dados obtidos. Também foram determinados matéria orgânica, $\mathrm{pH}$ em água, $\mathrm{P}$ e $\mathrm{K}$ disponíveis, e $\mathrm{Ca}$ e $\mathrm{Mg}$ trocáveis. A aplicação do dobro da dose de cama sobreposta de suínos aumenta os valores de C-BM e C-CO $\mathrm{CO}_{2}$ O qmic e o $q \mathrm{CO}_{2}$ são pouco afetados pela aplicação de dejetos de suínos. A aplicação do dobro da dose de cama sobreposta de suínos aumenta os valores de $\mathrm{pH}$ em água e os teores de $\mathrm{P}$ disponível e de Ca e Mg trocáveis no solo.

Termos para indexação: qualidade ambiental, plantio direto, esterco líquido suíno, qualidade do solo, suinocultura.

\section{Introduction}

Confined pig production generates liquid manure, from washing bays with water, and solid waste, such as deep litter (Jeppsson, 1999), generated by breeding pigs on organic material, which have been applied in no-tillage systems as a source of nutrients for crops. However, due to the large volume produced on swine raising properties and the small farm sizes, successive applications of manure are made on the same areas.

The application of manure, especially on degraded soils, can increase the accumulation of total organic carbon (TOC), particularly in the uppermost layers (Lourenzi et al., 2011). However, the speed of this increase is associated mainly with the composition, 
the frequency, and the quantity of the manure applied (Guardini et al., 2012). The manure may also contribute to an increase in exchangeable aluminum uptake, especially in the humic and fulvic acid fraction of the organic matter (Ceretta et al., 2003), decreasing plant toxicity and increasing $\mathrm{H}^{+}$adsorption (Lourenzi et al., 2011), which may lead to an increase in the values of the $\mathrm{pH}$ in water. Since the manure retains calcium and magnesium, derived mostly from commercial animal feed, over the years, an increase is expected in the exchangeable contents of soils with a history of pig slurry or deep pig litter application (Lourenzi et al., 2011). Moreover, continued applications of manure may cause an increase in the phosphorus and potassium contents on the soil surface as well as the occupation of adsorption surfaces, which will consequently reduce adsorption energy of these nutrients, increasing their desorption and availability (Ceretta et al., 2010a, 2010b).

In addition, the application of pig slurry or deep pig litter may lead to modifications in the soil microbiological attributes, such as microbial biomass carbon (MB-C). In spite of representing the lowest fraction of TOC (2 to 3\%), MB-C exhibits rapid cycling and responds significantly to seasonable fluctuations of moisture and temperature, and to the type of organic residue deposited (Balota et al., 2010). The high levels of labile $\mathrm{C}$ and low $\mathrm{C}: \mathrm{N}$ ratio in pig slurries stimulate the soil microbial population, increasing their size and activity. However, organic residues containing potentially toxic chemical elements may negatively affect soil microorganisms (Berton et al., 2006). In this case, the MB-C may be useful for providing rapid information on changes in the soil organic properties.

One of the indicators most used for evaluating the activity of heterotrophic soil microbiota is basal respiration, which represents the $\mathrm{CO}_{2}$ produced by the microbial biomass during the processes of decomposition and mineralization of the organic matter added to the soil (Moreira \& Siqueira, 2006). High values of basal respiration usually indicate greater metabolic activity of the microorganisms, since the flow of $\mathrm{CO}_{2}$ is related to the intensity of the catabolic processes; however, high values of basal respiration of microorganisms may also indicate the loss of soil organic matter, mainly in situations in which $\mathrm{C}$ balance is negative (Parkin et al., 1996).
The metabolic quotient $\left(q \mathrm{CO}_{2}\right)$ is an index obtained by the ratio between the basal respiration of the microbial activity and the MB-C, which is also considered as a sensitive indicator of alterations in the ecosystem (Anderson \& Domsch, 1989). Changes in the $q \mathrm{CO}_{2}$ reflect the organic matter status of the soil, the efficiency of microbial $\mathrm{C}$ conversion, and the losses and stabilization of organic $\mathrm{C}$ by the mineral fraction of the soil. Therefore, its value may indicate if $\mathrm{C}$ accumulation or loss is occurring in the soil.

The objective of this work was to evaluate the microbiological and chemical attributes of a soil with a seven-year history of urea and swine manure application.

\section{Materials and Methods}

The experiment was carried out on a pig farm near the municipality of Braço do Norte, in the south of the state of Santa Catarina, Brazil (28 14'20.7"S, $49^{\circ} 13^{\prime} 55.5^{\prime \prime} \mathrm{W}$, at $300 \mathrm{~m}$ of altitude). The climate of the region is subtropical humid (Cfa according to Köppen), with an annual average temperature of $18.7^{\circ} \mathrm{C}$ and a mean annual rainfall of $1,471 \mathrm{~mm}$. The soil is classified as a Typic Hapludalf (Soil Survey Staff, 1999). Before setting up the experiment, soil analysis indicated in the 0-10 cm layer: $330 \mathrm{~g} \mathrm{~kg}^{-1}$ of clay; $33 \mathrm{~g} \mathrm{~kg}^{-1}$ of organic matter; $\mathrm{pH}$ in water of $5.1 ; 19 \mathrm{mg} \mathrm{dm}^{-3}$ of available $\mathrm{P}$ and $130 \mathrm{mg} \mathrm{dm}^{-3}$ of available K (both extracted by Mehlich 1); $0.8,3.0$, and $0.8 \mathrm{cmol}_{\mathrm{c}} \mathrm{dm}^{-3}$ of exchangeable $\mathrm{Al}$, $\mathrm{Ca}$, and $\mathrm{Mg}$, respectively (extracted by $\mathrm{KCl} 1 \mathrm{~mol} \mathrm{~L}^{-1}$ ); $\mathrm{CTC}_{\mathrm{pH}} 7.0$ of $11.9 \mathrm{cmol}_{\mathrm{c}} \mathrm{dm}^{-3}$; base saturation of $41.7 \%$ and $\mathrm{Al}$ saturation of $16.13 \%$.

Soil samples were collected from a naturalized pasture area predominantly of Paspalum notatum, P. plicatulum, Eryngium ciliatum, and Stylosanthes montevidensis, with a history of sporadic application of pig slurry on the soil surface and of crop succession of maize (Zea mays) and black oat (Avena strigosa). In December 2002, 6.0 Mg ha-1 of limestone were applied (PRNT $=87.5 \%)$ on the soil surface, without incorporation, to raise $\mathrm{pH}$ in water up to 6.0 (Recomendações de adubação e de calagem para os Estados do Rio Grande do Sul e Santa Catarina, 1994). In January 2003, the pasture was desiccated. The five treatments were: control; U90 and U180, annual fertilization with urea at rates of 90 and $180 \mathrm{~kg} \mathrm{ha}^{-1}$ N; PS90 and PS180, pig slurry at rates of 90 and 
$180 \mathrm{~kg} \mathrm{ha}{ }^{-1} \mathrm{~N}$; and DL90 and DL180, annual fertilization with pig deep-litter at rates of 90 and $180 \mathrm{~kg} \mathrm{ha}^{-1} \mathrm{~N}$. The recommended quantity for $\mathrm{N}$ in pig slurry and deep litter was $90 \mathrm{~kg} \mathrm{ha}^{-1}$ per year for maize and black oat succession in the no-till system, according to the Comissão de Fertilidade do Solo (Recomendações de adubação e de calagem para os Estados do Rio Grande do Sul e Santa Catarina, 1994). To calculate doses of manure, the total $\mathrm{N}$ content of each kind of manure was used, the residual effect of these materials on $\mathrm{N}$ availability in the second year was not considered, and doses of 90 and $180 \mathrm{~kg} \mathrm{~N}$ were maintained over the years. Urea and manure were the only sources of nutrients added to the crop succession over the years. A randomized complete block design was used, with three replicates, and each experimental plot was $27 \mathrm{~m}^{2}(4.5 \mathrm{~m}$ width $\times 6.0 \mathrm{~m}$ length).

Twenty-eight applications of urea and pig slurry were made during the experimental period from 2002 to 2009 (four applications per year during the growing of maize and black oat). Urea was applied on the vegetative stage (V1), elongation stage (V6), and at tasseling in the maize crop, and at the beginning of tillering in the black oat crop. Doses of 90 and $180 \mathrm{~kg}$ $\mathrm{N}$ of pig slurry were divided into four equal doses over the maize and black oat crops: before maize sowing; 51 and 95 days after maize sowing; and 15 days after black oat sowing. In the same period (2002-2009), seven applications of deep litter were made, each one on the soil surface around 15 to 30 days before maize sowing. Maize was sown annually in November in rows with 50,000 plants per hectare, whereas black oat was broadcast seeded every year in April/May at a quantity of $90 \mathrm{~kg}$ of seeds per hectare.

In each plot, ten soil subsamples were collected at the 0-10 cm layer on 10/17/2008, 12/18/2008, 2/18/2009, $3 / 23 / 2009,6 / 4 / 2009,8 / 21 / 2009$, and $10 / 12 / 2009$. After collection, the samples were taken to the laboratory and were passed through a $2 \mathrm{~mm}$ mesh sieve. Plant fragments were removed manually and soil moisture was adjusted to $60 \%$ field capacity with the addition of distilled water. After that, soil samples were stored in a refrigerator at $4^{\circ} \mathrm{C}$ for ten days. Subsequently, the MB-C was analyzed in triplicate, subdivided into six subsamples of $30 \mathrm{~g}$, of which three were subjected to radiation in a microwave oven to cause cell lysis. The samples were subjected to microwave radiation for $2 \mathrm{~min}$ at $1.62 \times 10^{5} \mathrm{~J}$ (Ferreira et al., 1999). Then, the organic $\mathrm{C}$ samples (radiated and non-radiated) were extracted with a solution of potassium sulfate $\left(0.5 \mathrm{~mol} \mathrm{~L} \mathrm{~K}^{-1} \mathrm{~K}_{2} \mathrm{SO}_{4}\right)$, oxidized by a solution of potassium dichromate $\left(0.066 \mathrm{~mol} \mathrm{~L}^{-1}\right.$ $\mathrm{K}_{2} \mathrm{Cr}_{2} \mathrm{O}_{7}$ ), and titrated with a solution of ammonium ferrous sulfate $\left[0.033 \mathrm{~mol} \mathrm{~L}^{-1} \mathrm{FeSO}_{4}\left(\mathrm{NH}_{4}\right) 2 \mathrm{SO}_{4} \cdot 6 \mathrm{H}_{2} \mathrm{O}\right]$. The coefficient $(\mathrm{Kc})$ used in the calculation to determine the MB-C was 0.33. Soil basal respiration (BR) was determined according to Jenkinson \& Powlson (1976). The $q \mathrm{CO}_{2}$ was obtained through the ratio BR / MB-C (Anderson \& Domsch, 1993). The qmic was obtained by the ratio MB-C / TOC (Anderson \& Domsch, 1989), in which the soil TOC was determined by the wet oxidation method for organic matter (Walkley-Black) (Tedesco et al., 1995).

In October 2008 and 2009, soil was collected from the $0-10 \mathrm{~cm}$ layer. After collection, soil samples were air-dried, passed through a $2 \mathrm{~mm}$ mesh sieve, and subjected to TOC analysis. The following were calculated with the obtained data: organic matter content (Donagema et al., 2011); $\mathrm{pH}$ in water (1:1), $\mathrm{Ca}$ and $\mathrm{Mg}$ exchangeable contents $\left(\mathrm{KCl} 1 \mathrm{~mol} \mathrm{~L}^{-1}\right.$ extractor); available $\mathrm{P}$ and $\mathrm{K}$ (Mehlich 1 extractor) (Tedesco et al., 1995).

The results of the microbiological and chemical attributes were tested as to normality by the Kolmogorov-Smirnov method and subjected to analysis of variance. When significant, mean values of chemical attributes were compared by Tukey's test, at $5 \%$ probability, and mean values of microbiological attributes were compared by Duncan's test, at 5\% probability. All the attributes were subjected to principal component analysis (PCA), in which the microbiological attributes of the soil collected on $10 / 17 / 2008,12 / 18 / 2008,2 / 18 / 2009$, and 3/23/2009 represented the maize cycle, and of the soil collected on $6 / 4 / 2009,8 / 21 / 2009$, and $10 / 12 / 2009$ characterized the black oat cycle. The soil chemical attributes, collected in October 2008 and 2009, corresponded to the maize and black oat cycle, respectively. To reduce discrepancy among the data, the quantitative values were normalized through the equation: [(value - minimum value)/maximum value - minimum value) $\mathrm{x} 2$ ] -1 .

\section{Results and Discussion}

No significant differences were observed among treatments for MB-C in the soil collected in October 
2008 (Table 1). In December 2008, the MB-C content in the soil subjected to the application of twice the dose of deep pig litter (DL180) was greater than in the control. In February 2009, the MB-C in the soil subjected to the application of DL180 was greater than in the soil of the other treatments. The MB-C also showed highest contents in the soil of the DL180 treatment in March, differing from the control, U90, U180, and DL 90 treatments. However, in June 2009, the soil of the treatments PS180, DL90, and DL180 presented the highest MB-C contents, which were higher than in the soil of the U90 treatment. In August and October 2009, the soil of DL180 treatment once more showed the highest values of MB-C, differing from the control, U90, U180, and PS90 treatments on the next-to-last date of assessment and from the PS180 and U90 treatments on the last date. The U90 treatment presented the lowest values on these last two dates of soil collection.

Although the MB-C values found are lower than those usually reported in the literature (Guerrero et al., 2007), they are in accordance with studies carried out in Brazil (Santos et al., 2012) and other countries (Liu et al., 2013). The differences in MB-C values can be explained by the fact that the soil microbial biomass is highly variable, dependent on environmental conditions such as the soil type, climate, and culture (Moreira \& Siqueira, 2006).

The highest MB-C content in the soil subjected to the application of DL180 on most of the dates may be attributed to the application of $30 \mathrm{~kg} \mathrm{ha}^{-1}$ TOC throughout the seven experimental years, a quantity greater than the 15,10 , and $20 \mathrm{~kg} \mathrm{ha}^{-1}$ per year of TOC added to the soil on the DL90, PS90, and PS180 treatments, respectively. The greater MB-C content in the soil may also be a result of the more recalcitrant forms of $\mathrm{C}$ in the deep pig litter than in the pig slurry (Giacomini \& Aita, 2008), which is easily decomposable and, therefore, has slower mineralization and, consequently, lower increase in the solution or even in the microbial biomass (Gessner et al., 2010). Furthermore, the carbon increase of the microbial biomass in the PS180 treatment may be associated with the application of the manure in the soil, which contained, in average, 30, 8, and $27 \mathrm{~kg} \mathrm{ha}^{-1} \mathrm{~N}, \mathrm{P}$ and $\mathrm{K}$, respectively, and was carried out 15 days before soil collection. This result corroborates those obtained by Chu et al. (2007), who also found higher MB-C values in the soil with the application of organic fertilizer than with chemical fertilization with $\mathrm{N}, \mathrm{P}$, and $\mathrm{K}$.

Similar results were found for MB-C in the soil of the control, U90, and U180 treatments. The highest

Table 1. Carbon contents in the microbial biomass and basal respiration values in the $0-10 \mathrm{~cm}$ layer in soil subjected to the application of urea and swine manure for a period of seven years ${ }^{(1)}$.

\begin{tabular}{|c|c|c|c|c|c|c|c|}
\hline Treatment $^{(2)}$ & October 2008 & December 2008 & February 2009 & March 2009 & June 2009 & August 2009 & October 2009 \\
\hline & \multicolumn{7}{|c|}{ Microbial biomass carbon (mg kg-1 of dry soil) } \\
\hline Control & $53 \mathrm{Aa}$ & $47 \mathrm{ABd}$ & $54 \mathrm{Ab}$ & $54 \mathrm{Ab}$ & $53 \mathrm{Aab}$ & $37 \mathrm{Bbc}$ & 59Aabc \\
\hline U90 & $63 \mathrm{Aa}$ & $62 \mathrm{Abc}$ & $55 \mathrm{ABb}$ & $53 \mathrm{ABb}$ & $36 \mathrm{BCb}$ & $32 \mathrm{Cc}$ & 40BCc \\
\hline U180 & $55 \mathrm{Aa}$ & $57 \mathrm{Abcd}$ & $51 \mathrm{ABb}$ & $54 \mathrm{Ab}$ & $58 \mathrm{Aab}$ & $38 \mathrm{Bbc}$ & $55 \mathrm{Aabc}$ \\
\hline PS90 & 40Da & $56 \mathrm{BCbcd}$ & $53 \mathrm{BCb}$ & $67 \mathrm{Aab}$ & 49CDab & $41 \mathrm{Dbc}$ & 61ABabc \\
\hline PS180 & $44 \mathrm{Ba}$ & 57Abcd & $56 \mathrm{ABb}$ & $63 \mathrm{ABab}$ & $62 \mathrm{ABa}$ & 48ABab & $51 \mathrm{ABbc}$ \\
\hline DL90 & $45 \mathrm{Ba}$ & $52 \mathrm{ABcd}$ & $55 \mathrm{ABb}$ & $56 \mathrm{ABb}$ & $63 \mathrm{ABa}$ & $44 \mathrm{Babc}$ & 66Aab \\
\hline \multirow[t]{2}{*}{ DL180 } & $59 \mathrm{ABa}$ & $75 \mathrm{ABa}$ & $71 \mathrm{ABa}$ & $71 \mathrm{ABa}$ & $61 \mathrm{ABa}$ & $56 \mathrm{Ba}$ & $77 \mathrm{Aa}$ \\
\hline & \multicolumn{7}{|c|}{ Basal respiration $\left(\mathrm{C}^{-} \mathrm{CO}_{2}, \mathrm{mg} \mathrm{kg}^{-1}\right.$ per hour $)$} \\
\hline Control & $0.81 \mathrm{ABa}$ & $0.74 \mathrm{Bb}$ & $1.08 \mathrm{Ac}$ & $1.10 \mathrm{Aa}$ & $0.91 \mathrm{ABa}$ & $0.91 \mathrm{ABa}$ & $0.67 \mathrm{Bab}$ \\
\hline U90 & $0.70 \mathrm{BCa}$ & $0.46 \mathrm{Cb}$ & $0.98 \mathrm{ABc}$ & $0.89 \mathrm{ABa}$ & 1.10Aa & $1.01 \mathrm{ABa}$ & $0.42 \mathrm{Cb}$ \\
\hline U180 & $0.70 \mathrm{Ba}$ & $0.83 \mathrm{ABb}$ & $0.97 \mathrm{ABc}$ & $0.85 \mathrm{ABa}$ & $1.44 \mathrm{Aa}$ & $0.98 \mathrm{ABa}$ & $0.84 \mathrm{ABab}$ \\
\hline PS90 & $0.88 \mathrm{Aa}$ & $0.84 \mathrm{Aab}$ & $0.95 \mathrm{Ac}$ & $1.12 \mathrm{Aa}$ & $1.03 \mathrm{Aa}$ & $1.12 \mathrm{Aa}$ & 0.76Aab \\
\hline PS180 & $0.80 \mathrm{Aa}$ & $0.81 \mathrm{Aab}$ & $1.00 \mathrm{Ac}$ & $0.80 \mathrm{Aa}$ & $0.92 \mathrm{Aa}$ & $0.86 \mathrm{Aa}$ & $0.84 \mathrm{Aab}$ \\
\hline DL90 & $0.75 \mathrm{Ba}$ & $0.76 \mathrm{Bab}$ & $1.45 \mathrm{Ab}$ & $0.89 \mathrm{Ba}$ & $1.07 \mathrm{ABa}$ & $1.12 \mathrm{ABa}$ & $0.79 \mathrm{Bab}$ \\
\hline DL180 & $0.78 \mathrm{Ba}$ & $1.36 \mathrm{ABa}$ & $1.98 \mathrm{Aa}$ & $1.00 \mathrm{Ba}$ & $1.23 \mathrm{Ba}$ & $1.08 \mathrm{Ba}$ & $1.40 \mathrm{ABa}$ \\
\hline
\end{tabular}


contents were observed from October 2008 to June 2009, and the lowest in August 2009 (Table 1). The soil of the treatments with the application of deep pig litter at one and two times the recommended amount presented the highest contents in October 2009. The lowest MB-C content was registered in August 2009 in all the treatments, with the exception of PS180, in which it was observed in October 2008.

The biomass captured organic $\mathrm{C}$ derived from the mineralization of $\mathrm{C}$ that was more easily decomposed from pig slurry (PS90 and PS180), including $\mathrm{C}$ of the soil subjected to the application of urea (U90 and U180). In the soil of these two treatments, it is probable that part of the $\mathrm{C}$ was derived from the crop residue of maize and, especially, from black oats in decomposition on the soil surface. That is because, throughout the years, dry matter production of maize and black oat did not differ among the treatments. However, in the treatments with the application of deep pig litter, material with a high $\mathrm{C}: \mathrm{N}$ ratio is provided to the soil microbial biomass, with $\mathrm{C}$ being highly recalcitrant. This makes an immediate colonization of the microbial biomass impossible in this substrate.

It is important to note that the microbial biomass first degrades the substrates recently added to the soil, or part of them, which contain a source of labile $\mathrm{C}$, like that of the pig slurry. In the second phase, there is an increase of the biomass activity and of the consumption of the remaining substrates, which are more utilizable than those normally present in the soil. Finally, the substrates reach a state similar to the initial one of the soil, and there is the decline of microbial activity and of the biomass.

The basal respiration values in December 2008, February, and October 2009 were higher in the soil of the DL180 treatment (Table 1). In February 2009, the soil of the DL90 treatment (deep pig litter at recommended level) presented a basal respiration value lower than that observed in the soil of the DL180 treatment. However, these values were higher than those verified in the soil of the other treatments (control, U90, U180, PS90, PS180), which did not differ on any collection date. A possible explanation is that deep pig litter normally has a high $\mathrm{C}: \mathrm{N}$ ratio and high lignin contents, which retards its decomposition, increasing colonization by specialized microorganisms equipped with more complex enzymatic systems capable of degrading molecules of greater weight, probably polymerized (Gessner et al., 2010). As the microorganisms release enzymes for the initial rupture of those molecules, other less specialized microorganisms find conditions for proliferation, which may be reflected in higher breathing values. These results are similar to those obtained by Ros et al. (2007), who reported higher basal respiration values in a soil subjected to the application of deep pig litter from November 2002 to May 2003 than in the soil with the application of pig slurry.

Throughout the collection dates, the basal respiration values oscillated in the soil in most of the treatments, with the exception of PS90 and PS180 (Table 1). In the soil of the control treatment, the higher value of $\mathrm{CO}_{2}$ released by the microbial biomass was observed in February and March 2009, which may be explained by the higher air temperatures at this time of the year. As for the treatments U90 and U180, the greatest value was observed in June 2009. However, a reduction in the basal respiration value from the control soil and U90 treatments was registered in December 2008 and October 2009; whereas in the U180 treatment, the lowest value was observed in October 2008.

In the soil of the treatments with the application of deep pig litter, at one and two times the recommended dose of $\mathrm{N}$, a peak in the release of $\mathrm{CO}_{2}$ was observed in February 2009, and basal respiration reached its highest values. This can be attributed to the fact that deep pig litter was applied soon after the first soil collection (October 2008). This material has larger particles, with a high $\mathrm{C}: \mathrm{N}$ ratio and greater surface for bacterial colonization and reaction than in the other treatments (Masse et al., 2005). This delays the microbial attack at first, and the degradation is slower, occurring for a longer period of time, which helps to explain the greater $\mathrm{CO}_{2}$ emissions after approximately 90 days from the application of organic matter in the soil of these treatments. Moreover, the increase in air temperature in February 2009 may have assisted microbial biomass in the decomposition of the deep pig litter and in the release of $\mathrm{CO}_{2}$ to the atmosphere (Hoyle et al., 2006). However, with the application of pig slurry, which has low $\mathrm{C}: \mathrm{N}$ ratio and small-sized particles, the microbial attack, its degradation, and the $\mathrm{CO}_{2}$ emissions occur rapidly, in a matter of days (Chantigny et al., 2004), explaining in part why there was no oscillation of the basal respiration values in the DL90 and DL180 treatments. 
The qmic values did not differ among treatments, with mean value of $0.32 \%$. The $q$ mic expresses how much of the soil organic $\mathrm{C}$ is contained in the microbial biomass, showing the efficiency of the microorganisms in immobilizing it. The $q$ mic values generally ranged from 0.2 to $6 \%$ of the soil organic C. Low values of the qmic may be a result of a stress factor to which the microbiota is subjected to (Jakelaitis et al., 2008), making it unable to use readily available $\mathrm{C}$ derived from soil organic matter or organic residue, which may hinder the use of $\mathrm{C}$ by the microbial biomass. With the application of increasing doses of swine manure in Oxisol under no-tillage, Balota et al. (2012) verified that the qmic ranged from 1.2 to $2 \%$ of TOC and that the values increased up to a dose of $60 \mathrm{~m}^{3} \mathrm{ha}^{-1}$; however, a slight decrease was observed in the $q$ mic values with the application of a dose of $120 \mathrm{~m}^{3} \mathrm{ha}^{-1}$ of swine manure.

The $q \mathrm{CO}_{2}$ values did not differ among the treatments, with mean value of $18.7 \mu \mathrm{g} \mathrm{C}-\mathrm{CO}_{2} \mathrm{~g}^{-1}$ MB-C per hour. This index represents the quantity of $\mathrm{C}$ released in the form of $\mathrm{CO}_{2}$ per unit of microbial biomass at a determined time. When high, these values indicate microbial communities in initial stages of development or derived from some type of metabolic stress (Anderson \& Domsch, 1993). This shows that the microbial community present in the soil of the assessed treatments was stabilized. Therefore, the C used by the microbial biomass was equally distributed in the treatments, agreeing with the results obtained by Guerrero et al. (2007) with the application of deep pig litter and pig slurry in a limestone soil in Spain.

No significant differences were observed in organic matter contents among the treatments in the soil collected in October 2008 and 2009 (Table 2). It is important to note that even in the control treatment, which did not receive the application of manure throughout the experiment, the organic matter contents remained similar to those of the other treatments with the application of urea (U90 and U180), pig slurry (PS90 and PS180), and deep pig litter (DL90 and DL180). Normally, the TOC content in soil is expected to increase with added organic wastes with high $\mathrm{C}: \mathrm{N}$ ratio, such as, deep litter. However, this was not evaluated in the present work, which could be explained by the deposition of maize and black oat waste in the soil surface over the years. In a long-term experiment in northeast China, Kou et al. (2012) observed that the treatment under soybean cultivation, with the application of $23 \mathrm{~kg} \mathrm{ha}^{-1}$ of horse manure and the removal of crop residues from the soil surface, showed the same levels of TOC in the soil as the control treatment (natural field), where crop residues were kept on the soil surface. According to Manfogoya

Table 2. Organic matter, $\mathrm{pH}$ in water, available $\mathrm{P}$ and $\mathrm{K}$, exchangeable $\mathrm{Ca}$ and $\mathrm{Mg}$ in the $0-10 \mathrm{~cm}$ layer in a soil with a history of application of urea and swine manure for a period of seven years ${ }^{(1)}$.

\begin{tabular}{|c|c|c|c|c|c|c|}
\hline Treatment $^{(2)}$ & $\begin{array}{c}\text { Organic matter } \\
\left(\mathrm{g} \mathrm{kg}^{-1}\right)\end{array}$ & $\begin{array}{c}\mathrm{pH} \\
\text { in water }\end{array}$ & $\begin{array}{c}\text { Available P } \\
\left(\mathrm{mg} \mathrm{dm}^{-3}\right)\end{array}$ & $\begin{array}{c}\text { Available K } \\
\left(\mathrm{mg} \mathrm{dm}^{-3}\right)\end{array}$ & $\begin{array}{c}\text { Exchangeable Ca } \\
\left(\mathrm{cmol}_{\mathrm{c}} \mathrm{dm}^{-3}\right)\end{array}$ & $\begin{array}{c}\text { Exchangeable } \mathrm{Mg} \\
\left(\mathrm{cmol}_{\mathrm{c}} \mathrm{dm}^{-3}\right)\end{array}$ \\
\hline & \multicolumn{6}{|c|}{ October 2008} \\
\hline Control & $15.6 \mathrm{a}$ & $5.5 \mathrm{a}$ & $9.9 \mathrm{~b}$ & $123.3 b$ & $4.1 \mathrm{~b}$ & $1.4 \mathrm{~b}$ \\
\hline U90 & $16.2 \mathrm{a}$ & $5.3 \mathrm{a}$ & $6.8 \mathrm{~b}$ & $158.7 \mathrm{ab}$ & $4.1 \mathrm{~b}$ & $1.4 \mathrm{~b}$ \\
\hline U180 & $15.0 \mathrm{a}$ & $5.4 \mathrm{a}$ & $8.4 b$ & $125.3 \mathrm{~b}$ & $4.2 \mathrm{~b}$ & $1.4 \mathrm{~b}$ \\
\hline PS90 & $16.8 \mathrm{a}$ & $5.5 \mathrm{a}$ & $14.4 \mathrm{~b}$ & $183.3 \mathrm{ab}$ & $4.3 \mathrm{ab}$ & $2.1 \mathrm{ab}$ \\
\hline PS180 & $16.2 \mathrm{a}$ & $5.1 \mathrm{a}$ & $22.9 b$ & $167.3 \mathrm{ab}$ & $4.2 \mathrm{ab}$ & $1.9 \mathrm{ab}$ \\
\hline DL90 & $16.8 \mathrm{a}$ & $5.9 \mathrm{a}$ & $35.3 b$ & $279.3 \mathrm{ab}$ & $5.5 \mathrm{ab}$ & $1.8 \mathrm{ab}$ \\
\hline \multirow[t]{2}{*}{$\underline{\text { DL180 }}$} & $19.1 \mathrm{a}$ & $6.2 \mathrm{a}$ & $81.0 \mathrm{a}$ & $388.0 \mathrm{a}$ & $6.7 \mathrm{a}$ & $2.8 \mathrm{a}$ \\
\hline & \multicolumn{6}{|c|}{ October 2009} \\
\hline Control & $14.5 \mathrm{a}$ & $5.8 \mathrm{ab}$ & $10.0 \mathrm{~b}$ & $128 \mathrm{bc}$ & $3.3 \mathrm{bc}$ & $1.2 \mathrm{~b}$ \\
\hline U90 & $15.0 \mathrm{a}$ & $5.2 b$ & $31.0 \mathrm{~b}$ & $182 \mathrm{abc}$ & $2.4 \mathrm{c}$ & $1.3 b$ \\
\hline U180 & $14.5 \mathrm{a}$ & $5.4 \mathrm{ab}$ & $15.6 b$ & $111 \mathrm{c}$ & $2.5 \mathrm{c}$ & $1.2 \mathrm{~b}$ \\
\hline PS90 & $15.6 \mathrm{a}$ & $6.0 \mathrm{ab}$ & $59.4 \mathrm{ab}$ & $145 \mathrm{abc}$ & $3.8 \mathrm{abc}$ & $1.6 \mathrm{ab}$ \\
\hline PS180 & $15.0 \mathrm{a}$ & $5.5 \mathrm{ab}$ & $82.0 \mathrm{ab}$ & $178 \mathrm{abc}$ & $3.1 b c$ & $1.6 \mathrm{ab}$ \\
\hline DL90 & $16.2 \mathrm{a}$ & $6.1 \mathrm{ab}$ & $135.5 \mathrm{a}$ & $313 \mathrm{ab}$ & $4.7 \mathrm{ab}$ & $1.9 \mathrm{ab}$ \\
\hline DL180 & $17.4 \mathrm{a}$ & $6.4 \mathrm{a}$ & $130.7 \mathrm{a}$ & $334 a$ & $5.4 \mathrm{a}$ & $2.4 \mathrm{a}$ \\
\hline
\end{tabular}

${ }^{(1)}$ Mean values followed by equal letters, lowercase in the columns, do not differ by Tukey's test, at 5\% probability. ${ }^{(2)} \mathrm{U} 90$, mineral nitrogen fertilization at recommended level; U180, mineral nitrogen fertilization two times the recommended level; PS90, pig slurry at recommended level; PS180, pig slurry two times the recommended level; DL90, deep pig litter at recommended level; DL180, deep pig litter two times the recommended level. 
et al. (1997), annual additions of approximately 7 to $10 \mathrm{Mg} \mathrm{ha}^{-1}$ residues with a high $\mathrm{C}: \mathrm{N}$ ratio, such as tissue oat, may maintain TOC and, therefore, organic matter over the years. In the control treatment, only $6.5 \mathrm{Mg} \mathrm{ha}^{-1}$ of oat residues were added annually, excluding residue inputs for maize.

Soil $\mathrm{pH}$ values did not differ among treatments in October 2008. However, in October 2009, the soil $\mathrm{pH}$ value was higher in the DL180 treatment than in the U90 treatment and, in general, than in the other treatments. This occurred because deep pig litter is composed by a higher $\mathrm{CaCO}_{3}$ content, derived from animal feed, due to a higher percentage of dry matter in relation to pig slurry (Whalen et al., 2000). In addition, the decomposition of deep pig litter and of the crop residues deposited on the soil surface throughout the years released organic acids in the soil, increasing the adsorption of $\mathrm{H}^{+}$and $\mathrm{Al}^{+3}$, which may promote the increase in $\mathrm{pH}$ values and the reduction of the exchangeable $\mathrm{Al}^{+3}$ contents (Lourenzi et al., 2011).

The greatest $\mathrm{P}$ content available in the soil collected in October 2008 was observed in the treatment with the application of twice the dose of deep pig litter (DL180) (Table 2). In the soil collected in October 2009 , the greatest contents were usually observed in the PS90, PS180, and, especially, the DL90 and DL180 treatments. Higher P contents are available in soils with the application of manure, which already contain the element in their composition, and the concentration is higher in residues with greater dry matter content, such as deep pig litter, which is reflected in higher accumulation in the soil (Guardini et al., 2012).

The higher exchangeable $\mathrm{Ca}$ and $\mathrm{Mg}$ contents in the soil collected in October 2008 and 2009 were obtained in the PS90, PS180, DL90, and DL180 treatments. This is attributed to the $\mathrm{Ca}$ and the $\mathrm{Mg}$ contained in the swine manure and in the deep pig litter, which are mineralized when added to the soil.

The principal component analyzis showed, through the relation between principal component 1 (CP1, factor 1) and principal component 2 (CP2, factor 2), that there was a separation between the treatments in the 2008/2009 maize crop season (Figure 1 A) and in the 2009 black oat crop season (Figure 1 B). In the maize cycle, the DL90, DL180, and PS180 treatments were separated by the CP1, which explains $57.09 \%$ of the results, and differed from the other treatments (control, U90, U180, and PS90).
The microbiological attributes that most contributed to this separation were the $q \mathrm{CO}_{2}$ and basal respiration; and, within the chemical attributes, the organic matter content, exchangeable $\mathrm{Ca}$, exchangeable $\mathrm{Mg}$, available
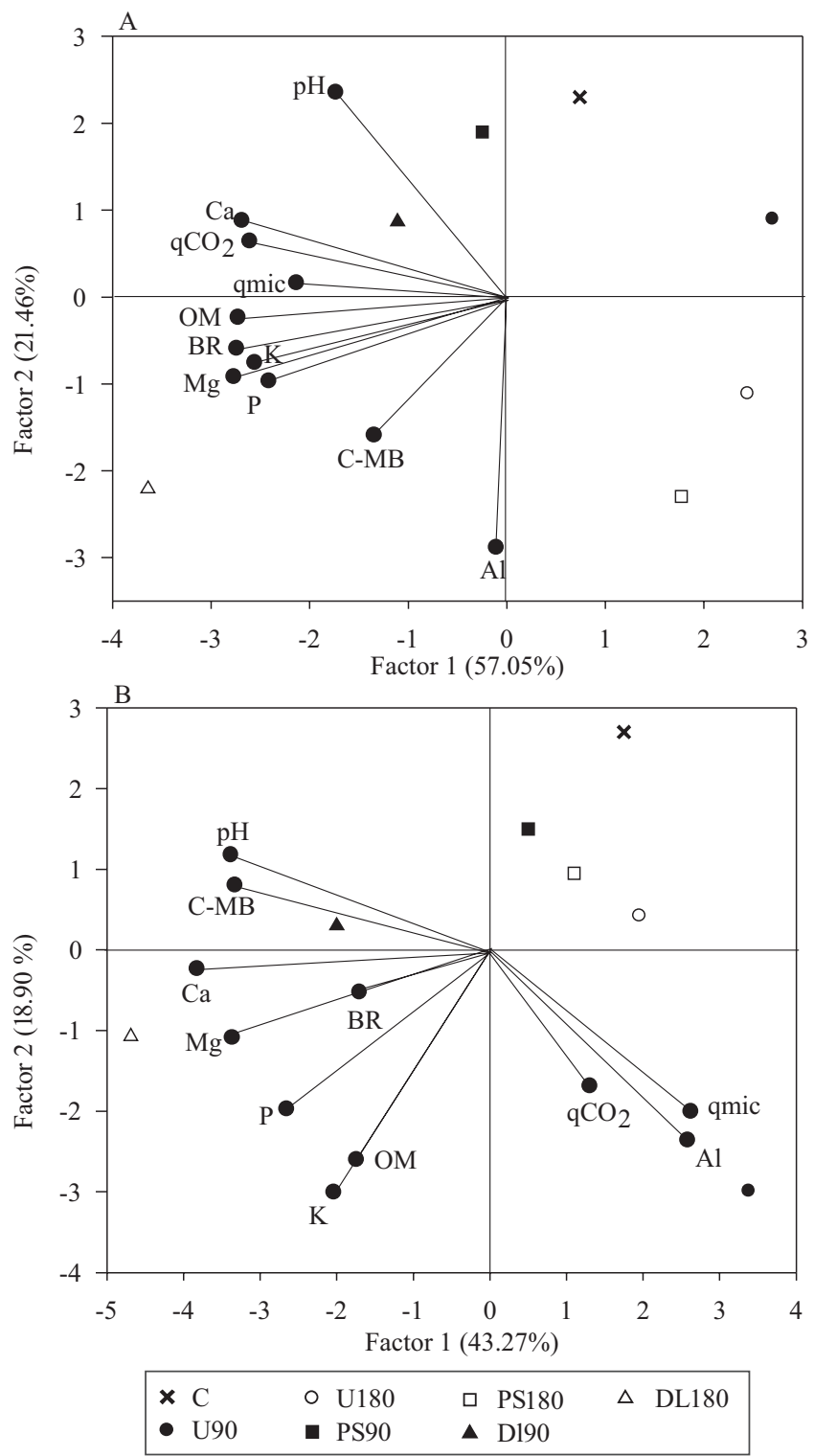

Figure 1. Relation between principal component 1 (factor 1) and principal component 2 (factor 2), during the 2008/2009 maize crop season (A) and the 2009 black oat crop season (B). Chemical and microbiological attributes: $\mathrm{pH}, \mathrm{pH}$ in water; $\mathrm{P}$, available phosphorus; $\mathrm{K}$, available potassium; $\mathrm{Ca}$, exchangeable calcium; $\mathrm{Mg}$, exchangeable magnesium; $\mathrm{OM}$, organic matter; $\mathrm{Al}$, exchangeable aluminum; $\mathrm{MB}-\mathrm{C}$, microbial biomass carbon; $\mathrm{BR}$, basal respiration; $q \mathrm{CO}_{2}$, metabolic quotient; and qmic, microbial quotient. 
$\mathrm{P}$ and $\mathrm{K}$. That reflects a strong relation between soil organic matter and microbial activity, showing the effect caused by the addition of $\mathrm{P}$ and $\mathrm{K}$, and by the $\mathrm{C}: \mathrm{N}$ ratio of the fertilizers added to the soil, which may have affected the results. The microbial biomass needs $\mathrm{C}$ to maintain its metabolic activities, and, when there is a greater increase of readily mineralizable $\mathrm{N}$ than $\mathrm{C}$, the biomass suffers some type of stress (Delbem et al., 2011), which explains the form of grouping adopted for the assessed treatments.

Factor 2 separates the U90, PS90, and DL90 treatments from the U180, PS180, and DL180 treatments, showing the effect of fertilization on the characteristics of the treatments. Soil microorganisms depend on other nutrients, such as available $\mathrm{P}$ and available $\mathrm{K}$, for their survival, which have greater availability in the treatments with the application of twice the dose of manure; therefore, separating the evaluated treatments. This result is due to the fact that in the PCA of the maize crop (Figure $1 \mathrm{~A}$ ), the biological (basal respiration, $q \mathrm{CO}_{2}$, and $q$ mic) and the chemical attributes (exchangeable $\mathrm{Ca}$, organic matter, available $\mathrm{P}$ and $\mathrm{K}$, and exchangeable $\mathrm{Mg}$ ) are found to be strongly related, showing the effect of large quantities of nutrients on microbial activity.

In the 2009 crop season of black oat, the DL90 and DL180 treatments were separated from the others by factor 1, which explains $43.27 \%$ of the results (Figure 1 B). This result is similar to those found in the 2008/2009 maize crop season (Figure 1 A), showing the strong effect of fertilization with deep pig litter on the characteristics of the treatments. The chemical attributes $\mathrm{pH}$, available $\mathrm{P}$ and $\mathrm{K}$, organic matter, exchangeable $\mathrm{Ca}$ and $\mathrm{Mg}$, and the microbiological attribute MB-C were those that most contributed to these results.

\section{Conclusions}

1. The application of once or twice the dose of deep pig litter increases the carbon of the microbial biomass and the basal respiration of the soil.

2. The microbial and metabolic quotients are little affected by the application of swine manure.

3. The application of twice the dose of deep pig litter increases the values of $\mathrm{pH}$ in water and the contents of available $\mathrm{P}, \mathrm{Ca}$, and $\mathrm{Mg}$ in the soil.

\section{References}

ANDERSON, T.H.; DOMSCH, K.H. Ratios of microbial biomass carbon to total organic carbon in arable soils. Soil Biology and Biochemistry, v.21, p.471-479, 1989. DOI: 10.1016/0038-0717(89)90117-X.

ANDERSON, T.H.; DOMSCH, K.H. The metabolic quotient $\left(q \mathrm{CO}_{2}\right)$ as a specific activity parameter to assess the effects of environmental conditions, such as $\mathrm{pH}$, on the microbial biomass of forest soils. Soil Biology and Biochemistry, v.25, p.393-395, 1993. DOI: 10.1016/0038-0717(93)90140-7.

BALOTA, E.L.; MACHINESKI, O.; MATOS, M.A. Soil microbial biomass under different tillage and levels of applied pig slurry. Revista Brasileira de Engenharia Agrícola e Ambiental, v.16, p.487-495, 2012. DOI: 10.1590/S1415-43662012000500004.

BALOTA, E.L.; MACHINESKI, O.; TRUBER, P.V. Soil carbon and nitrogen mineralization caused by pig slurry application under different soil tillage systems. Pesquisa Agropecuária Brasileira, v.45, p.515-521, 2010. DOI: 10.1590/S0100-204X2010000500011.

BERTON, R.S.; PIRES, A.M.M.; ANDRADE, S.A.L. de; ABREU, C.A. de; AMBROSANO, E.J.; SILVEIRA, A.P.D. da. Toxicidade do níquel em plantas de feijão e efeitos sobre a microbiota do solo. Pesquisa Agropecuária Brasileira, v.41, p.1305-1312, 2006. DOI: 10.1590/S0100-204X2006000800014.

CERETTA, C.A.; DURIGON, R.; BASSO, C.J.; BARCELLOS, L.A.R.; VIEIRA, F.C.B. Características químicas de solo sob aplicação de esterco líquido de suínos em pastagem natural. Pesquisa Agropecuária Brasileira, v.38, p.729-735, 2003. DOI: 10.1590/S0100-204X2003000600009.

CERETTA, C.A.; GIROTTO, E.; LOURENZI, C.R.; TRENTIN, G.; VIEIRA, R.C.B.; BRUNETTO, G. Nutrients transfer by runoff under no tillage in a soil treated with successive applications of pig slurry. Agriculture, Ecosystems and Environment, v.139, p.689-699, 2010a. DOI: 10.1016/j.agee.2010.10.016.

CERETTA, C.A.; LORENSINI, F.; BRUNETTO, G.; GIROTTO, E.; GATIBONI, L.C.; LOURENZI, C.R.; TIECHER, T.L.; CONTI, L. de; TRENTIN, G.; MIOTTO, A. Frações de fósforo no solo após sucessivas aplicações de dejetos de suínos em plantio direto. Pesquisa Agropecuária Brasileira, v.45, p.593-602, 2010b. DOI: 10.1590/S0100-204X2010000600009.

CHANTIGNY, M.H.; ROCHETTE, P.; ANGERS, D.A.; MASSÉ, D.; CÔTÉ, D. Ammonia volatilization and selected soil characteristics following application of anaerobically digested pig slurry. Soil Science Society of America Journal, v.68, p.306-312, 2004. DOI:10.2136/sssaj2004.3060.

CHU, H.; LIN, X.; FUJII, T.; MORIMOTO, S.; YAGI, K.; HU, J.; ZHANG, J. Soil microbial biomass, dehydrogenase activity, bacterial community structure in response to long-term fertilizer management. Soil Biology and Biochemistry, v.39, p.2971-2976, 2007. DOI: 10.1016/j.soilbio.2007.05.031.

DELBEM, F.C.; SCABORA, M.H.; SOARES FILHO, C.V.; HEINRICHS, R.; CROCIOLLI, C.A.; CASSIOLATO, A.M.R. Fontes e doses de adubação nitrogenada na atividade microbiana e fertilidade do solo cultivado com Brachiaria brizantha. Acta Scientiarum. Agronomy, v.33, p.361-367, 2011. DOI: 10.4025/ actasciagron.v33i2.3946. 
DONAGEMA, G.K.; CAMPOS, D.V.B. de; CALDERANO, S.B.; TEIXEIRA, W.G.; VIANA, J.H.M. (Org.). Manual de métodos de análise de solos. 2.ed. rev. Rio de Janeiro: Embrapa Solos, 2011. 230p. (Embrapa Solos. Documentos, 132).

FERREIRA, A.S.; CAMARGO, F.A.O.; VIDOR, C. Utilização de microondas na avaliação da biomassa microbiana do solo. Revista Brasileira de Ciência do Solo, v.23, p.991-996, 1999.

GESSNER, M.O.; SWAN, C.M.; DANG, C.K.; MCKIE B.G.; BARDGETT, R.D.; WALL, D.H.; HÄTTENSCHWILER, S. Diversity meets decomposition. Trends in Ecology and Evolution, v.25, p.372-380, 2010. DOI: 10.1016/j.tree.2010.01.010.

GIACOMINI, S.J.; AITA, C. Cama sobreposta e dejetos líquidos de suínos como fonte de nitrogênio ao milho. Revista Brasileira de Ciência do Solo, v.32, p.195-205, 2008. DOI: 10.1590/ S0100-06832008000100019.

GUARDINI, R.; COMIN, J.J.; SCHIMTT, D.E.; TIECHER, T.; BENDER, M.A.; RHEINHEIMER, D.S.; MEZZARI, C.P.; OLIVEIRA, B.S.; GATIBONI, L.C.; BRUNETTO, G. Accumulation of phosphorus fractions in typic Hapludalf soil after long-term application of pig slurry and deep pig litter in a no-tillage system. Nutrient Cycling in Agroecosystem, v.93, p.215-225, 2012. DOI: 10.1007/s10705-012-9511-3.

GUERRERO, C.; MORAL, R.; GÓMEZ, I.; ZORNOZA, R.; ARCENEGUI, V. Microbial biomass and activity of an agricultural soil amended with the solid phase of pig slurries. Bioresource Technology, v.98, p.3259-3264, 2007. DOI: 10.1016/j. biortech.2006.07.015.

HOYLE, F.C.; MURPHY, D.V.; FILLERY, I.R.P. Temperature and stubble management influence microbial $\mathrm{CO}_{2}-\mathrm{C}$ evolution and gross $\mathrm{N}$ transformation rates. Soil Biology and Biochemistry, v.38, p.71-80, 2006. DOI: 10.1016/j.soilbio.2005.04.020.

JAKELAITIS, A.; SILVA, A.A. da; SANTOS, J.B. dos; VIVIAN, R. Qualidade da camada superficial de solo sob mata, pastagens e áreas cultivadas. Pesquisa Agropecuária Tropical, v.38, p.118-127, 2008.

JENKINSON, D.S.; POWLSON, D.S. The effects of biocidal treatments on metabolism in soil-V: a method for measuring soil biomass. Soil Biology and Biochemistry, v.8, p.209-213, 1976. DOI: 10.1016/0038-0717(76)90005-5.

JEPPSSON, K.-H. Volatilization of ammonia in deep-litter systems with different bedding materials for young cattle. Journal of Agricultural Engineering Research, v.73, p.49-57, 1999. DOI: 10.1006/jaer.1998.0387.

KOU, T.J.; ZHU, P.; HUANG, S.; PENG, X.X.; SONG, Z.W.; DENG, A.X.; GAO, H.J.; PENG, C.; ZHANG, W.J. Effects of long-term cropping regimes on soil carbon sequestration and aggregate composition in rainfed farmland of Northeast China. Soil and Tillage Research, v.118, p.132-138, 2012. DOI: 10.1016/j. still.2011.10.018.
LIU, Y.; LI, X.; XING, Z.; ZHAO, X.; PAN, Y. Responses of soil microbial biomass and community composition to biological soil crusts in the revegetated areas of the Tengger Desert. Applied Soil Ecology, v.65, p.52-59, 2013. DOI: 10.1016/j.apsoil.2013.01.005.

LOURENZI, C.R.; CERETTA, C.A.; SILVA, L.S. da; TRENTIN, G.; GIROTTO, E.; LORENSINI, F.; TIECHER, T.L.; BRUNETTO, G. Soil chemical properties related to acidity under successive pig slurry applications. Revista Brasileira de Ciência do Solo, v.35, p.1827-1836, 2011. DOI: 10.1590/S0100-06832011000500037.

MANFOGOYA, P.L.; DZOWELA, B.H.; NAIR, P.K. Effect of multipurpose trees age of cutting and drying method on pruning quality. In: CADISCH, G.; GILLER, K.E. (Ed.). Driven by nature: plant litter quality and decomposition. Wallingford: $\mathrm{CAB}$ International, 1997. p.167-174.

MASSE, L.; MASSE, D.I.; BEAUDETTE, V.; MUIR, M. Size distribution and composition of particles in raw and anaerobically digested swine manure. Transactions of the ASAE, v.48, p.1943-1949, 2005.

MOREIRA, F.M.S.; SIQUEIRA, J.O. Microbiologia e bioquímica do solo. 2.ed. Lavras: Ufla, 2006. 729p.

PARKIN, T.B.; DORAN, J.W.; FRANCO-VIZCAINO, E. Field and laboratory tests of soil respiration. In: DORAN, J.W.; JONES, A.J. Methods for assessing soil quality. Madison: Soil Science Society of America, 1996. p.231-245.

RECOMENDAÇÕES de adubação e de calagem para os Estados do Rio Grande do Sul e Santa Catarina. 3.ed. Passo Fundo: Sociedade Brasileira de Ciência do Solo, Comissão de Fertilidade do Solo RS/SC, 1994. 224p.

ROS, M.; GARCÍA, C.; HERNANDEZ, M.T. Evaluation of different pig slurry composts as fertilizer of horticultural crops: effects on selected chemical and microbial properties. Renewable Agriculture and Food Systems, v.22, p.307-315, 2007. DOI: 10.1017/S1742170507001913.

SANTOS, V.B.; ARAÚJO, A.S.F.; LEITE, L.F.C.; NUNES, L.A.P.L.; MELO, W.J. Soil microbial biomass and organic matter fractions during transition from conventional to organic farming systems. Geoderma, v.170, p.227-231, 2012. DOI: 10.1016/j.geoderma.2011.11.007.

SOIL SURVEY STAFF. Soil taxonomy: a basic system of soil classification for making and interpreting soil surveys. Washington: US Government Printing Office, 1999.

TEDESCO, M.J.; GIANELlO, C.; BISSANI, C.A.; BOHNEN, H.; VOLKWEISS, S.J. Análises de solo, plantas e outros materiais. 2.ed. Porto Alegre: UFRGS, 1995. 174p. (UFRGS. Boletim técnico, 5).

WHALEN, J.K.; CHANG, C.; CLAYTON, G.W.; CAREFOOT, J.P. Cattle manure amendments can increase the $\mathrm{pH}$ of acid soils. Soil Science Society of America Journal, v.64, p.962-966, 2000. DOI: $10.2136 /$ sssaj2000.643962x.

Received on November 6, 2012 and accepted on June 28, 2013

Pesq. agropec. bras., Brasília, v.48, n.7, p.774-782, jul. 2013

DOI: 10.1590/S0100-204X2013000700010 